\title{
Mixing, Not Otherwise Specified
}

National Cancer Institute

\section{Source}

National Cancer Institute. Mixing, Not Otherwise Specified. NCI Thesaurus. Code

C113031.

Any mixing operation not otherwise specified. 